\title{
INITIATION TOWARDS WEB-BASED MUSEUM EXHIBITS IN MUZIUM KEDAH
}

\author{
Asmidah Alwi ${ }^{1}$ \\ School of Creative Industry Management and Performing Arts, \\ Universiti Utara Malaysia (UUM), Malaysia \\ (Email: asmidah@uum.edu.my) \\ Aeni Zuhana Saidin² \\ School of Multimedia Technology and Communication, \\ Universiti Utara Malaysia (UUM), Malaysia \\ (Email: aeni@uum.edu.my)
}

Accepted date: 01-09-2018

Published date: $30-06-2019$

To cite this document: Alwi, A. \& Saidin, A. Z. (2019). Initiation Towards Web-Based Museum Exhibits in Muzium Kedah. Journal of Tourism, Hospitality and Environment Management, 4(15), 01-09

DOI: $10.35631 / \mathrm{JTHEM} .415001$

\begin{abstract}
This paper reports an initial work in designing and implementing digital/virtual museum exhibits in the form of web-based environment for Muzium Kedah. The research objective was to investigate design elements of a web-based environment that can facilitate children museum learning experiences. The research study involved investigation of the physical environment of the museum as well as the existing museum website. Based on the finding, a small-scale web-based museum exhibits utilising a graphical and textual information representation formats was designed and developed. The data was collected in an experiment involved 12 school children age 9 to 12 years old. There were three dimensions being investigated: learning, effectiveness and appealing to assess the design of the web-based museum exhibits. The result shows positive impact on the children's museum learning experiences.
\end{abstract}

Keywords: Museum Learning, Museum Experience, Virtual Museum, Web-Based Exhibit, Muzium Kedah

\section{Introduction}

Museum in Malaysia has been established as early as 1883, and after the independence, the institution has become a symbol of Malaysian identity and carries the role of nation-building. For so long, museum exhibition in Malaysia was object-oriented, and that did not help much to engage visitor in the museum learning process. Apart from that, many museums in Malaysia also faces other challenges such as the needs to maintain financial performance, and also the needs to address and change the public perception of the museum as a dull entity (Taha, 2008). Therefore, museum in Malaysia have to consider drastic changes to find ways in ensuring its relevance in nowadays presence. In doing so, the Director General of the Department of Museum Malaysia revealed that Malaysian museums have then realized that 
they should re-emphasized and strengthen their educational roles so the great wealth of information hold by the museum could be utilized and support the formal education. To overcome the lacks, museums in Malaysia have taken a brave step by integrating their program with adopted schools' curriculum (Taha, 2008, Kechot et al., 2010) which has never been done before (although this is pretty common for museums in most developed countries). Additionally, Kechot, Hassan and Yunus (2010) finding shows that museum education could possibly facilitate the formal educational context; as it provides fun and effective learning. Thus, museum should consider the roles of a modern museum; not only preserves a heritage but more importantly to informs and entertains (Ahmad et. al., 2013) as well as to communicate knowledge (Ahmad et. al., 2014).

With the enhancement of technology and awareness of the needs and demands to integrate ICT aspects into the Malaysian museums environment has foreseen improvements in the physical space (Taha, 2008). However, with the rapid growth of the ICT tools, the demands are pointing towards digital exhibits and looking forwards for more interactivity in the museum exhibitions (Awang et al., 2009). To fulfil this ongoing demand, museum should explore the opportunity of using ICT tools to enhance the visitors' experience, taking into account the need of information, prior, during and after the museum visits. The Minister of Culture, Arts and Heritage has challenged the museums to be innovative and to comply with the international standards of museum exhibition, whereby utilizing the ICT tools perhaps could ease the process. We took that challenge by embarking on a museum website development initiative. Since the museum is a unique context where learning elements are part of the exhibition design, we have taken the approach to studying the children who are among the largest museum visitors.

\section{Children Learning in Museum}

Undeniably, children are important part of the museum visitors. They visit the museum either in school groups or with their family. Hence, there are possibilities that children learn from these informal contexts. Learning in context other than school is usually referred as informal learning or as Falk and Dierking (2000) termed it as free-choice learning. Since the nature of the informal environment, surely children's learning in school (the formal education system) is incomparable to the museum environment; hence not easily transferable from one to another due to the complex and very rich museum environment as it focuses on objects and exhibits (Andre, Durksen and Volman, 2017).

Initially, Piscitelli and Anderson (2001) argue on the lacking of research into museum experiences of young children despite the significant percentage of children visiting museums yearly. With recent development it can be seen that nowadays the situation has improved whereby in the Western countries, studies on children learning in museum have been quite well elaborated by focusing in various aspects of research. For example, see: Moorhouse et. al (2019), Birch (2018), Sutcliffe and Kim (2014), Alwi (2013) and Carr et. al. (2012). These studies took place in different types of museums with consideration of different children age groups including pre-schoolers. Among all, these studies explored how digital technologyenhanced or technology-supported exhibition has facilitated children museum experiential learning. Moorhouse et. al (2019) for instance, discussed about the children experiences with augmented reality (AR) in the museum. The findings reveal positive feedback from the children (aged 7-8 years old) as they found the AR experience to increase participants' engagement and interactivity with the environment. Besides that the implementation of the AR technology also evoked the children curiosity, facilitate new knowledge acquisition and encourage personal achievement (Moorhouse et. al 2019). 
On the other hand, Andre, Durksen and Volman (2017) who has reviewed articles on museum education research conducted within 1999 until 2012 timeframe proposed a framework that describes the strategies and activities facilitating children's learning in museums to conclude their findings (see Figure 1).
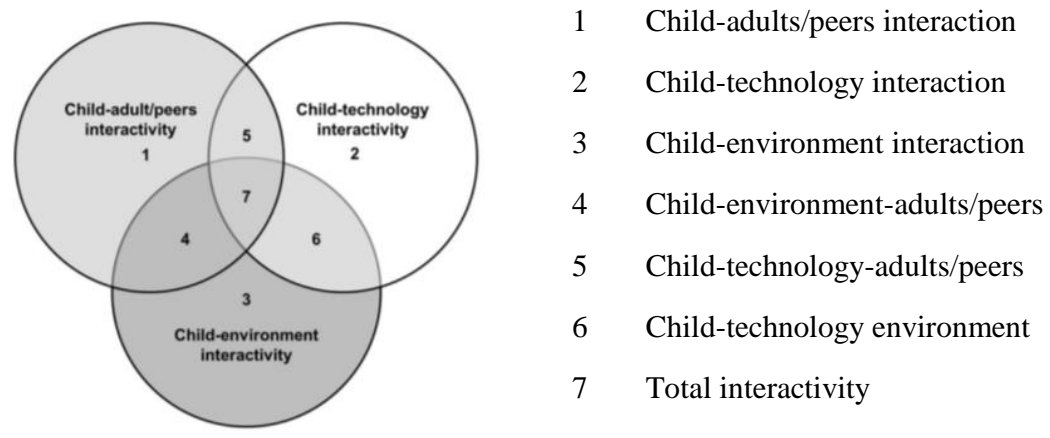

\section{Figure 1: The Framework Facilitating Strategies and Activities in Children's Learning in Museums (Andre, Durksen And Volman (2017), Pp. 52)}

Interesting fact about their finding is, on the technology involvement or implementation within the museum context which can presumably deem as essential. Nevertheless, research and understanding about children learning in museum within the Malaysian context is quite limited, particularly when involving the use of digital technology within the museum context. This therefore became the motivation towards the conduct of this study.

\section{Problem Statement}

Many museums in Malaysia already have their websites. However, from a preliminary observation of the Malaysian museums' websites, this online counterpart only serve to disperse basic information (such as opening hours, ticketing etcetera) hence frustratingly failed to fully utilize the technology for exhibition purposes. This research therefore would like to fit in the gap by looking into the possibility of enhancing the museum visiting experience through the online exhibits. Since Malaysia has a different approach to learning (compare to the western countries) we believe that a model derived from Malaysian context is necessary in helping the museums when designing for their online exhibits particularly to facilitate the learning experience. With this in mind, this research aims to investigate how museum learning can be implemented and encouraged through website design and then finally to propose a children-centered web-based exhibit prototype appropriate for that purpose. For the purpose of this paper, the discussion will only cover on the design and development of the web-based exhibit and evaluation of the web-based exhibits in terms of learning, effectiveness and appealing.

\section{Muzium Kedah as the Context of Investigation}

Kedah Museum was established on 3 February 1957 and during its establishment it was known as History Museum of Kedah. The museum was originally located on the ground floor of the Balai Besar but had to relocate due to growing collection of artifactss on December 30, 1961. The museum was later renamed as Kedah State Museum in July 1964. Now the Museum of Kedah is under the administration of Lembaga Muzium Kedah. Apart from the State Museum, there are other museums under the management of Lembaga Muzium Negeri 
Kedah, which are the Kedah Royal Museum, the Paddy Museum, Art Gallery and; Memorial and traditional houses. Each museum has its own building and situated in different locations.

Museum with the highest visiting number is the Paddy Museum (as shown in Figure 2) and followed closely by the Royal Museum. Paddy museum is dedicated in exhibiting artifacts regarding paddy planting as well as the representation of the local culture. Interestingly, the exhibition not only houses the artifacts related to traditional paddy planting processes, but also blended with the modern processing technique. On the other hand, the Royal Museum is devoted in exhibiting artifacts and information related to the Royal family of the Kedah sultanate of various generations. The museum is located in an old castle that was built in 1735 and has been Kedah administrative center of the $8^{\text {th }}$ century during the ruling of Almarhum Sultan Muhammad Jiwa Zainal Adilin Mu'adzam Shah II. As for the other museums; the exhibit values that lie within the building themselves such as the remains of the ancient and artistic value, the architectural knowledge as well as the historical information are the main attraction of these museums.

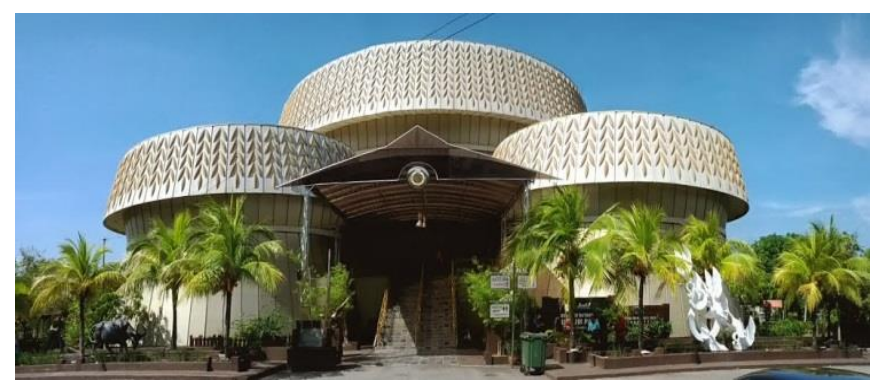

Figure 2: Muzium Padi, Kedah

Prior to conduct the research study, a decision needs to be made in determining the most appropriate exhibition to be utilised as the prototype. There are four main museums under the administration of Jabatan Muzium Kedah which are: Muzium Negeri, Muzium Padi, Muzium Diraja and Balai Seni. In addition, there are also a few traditional houses being administered by the Jabatan Muzium Negeri Kedah, for example, Rumah Tok Su. The research project has taken into consideration the unique nature of the Kedah group of museums during the development of the website, but for web-based exhibits design and development, the focus has been directed to only Muzium Padi and Muzium Diraja (as the context of investigation) considering the scale of the exhibition as well as the availability of the exhibition content.

\section{Methodology}

The research has been carried out in multiple phases in order to enable the researchers to get the overview of the current context of the museum. The most important objective was to investigate the physical museums settings (in order to have a better understanding of the nature of museums and the artifacts presented) as well as to explore the existing web-based museum (to find out what are being offered/represented in the museums' online context). It is also important to note that a suitable methodology should be in place to allow the researchers to study the museums' audiences/visitors with particular interest in capturing their requirements and needs towards enhancing their museum learning experiences. In this case, the research was more interested to understand about children's needs as museums are among the selected informal settings to support their formal learning (as explained in the literature review section). The research has been conducted in five phases which will be explained in the following sub-sections. 


\section{Preliminary Study}

To kick start the digitization process requires detail understanding of the current museum context. Information such as the main objectives of each museum and the nature of the exhibition will eventually shape the future development of its digital content. In order to have the overall understanding of the current context of the museums and to advocate the potential and possible things that can be done towards the digitization process of the museum. To do so, a series of discussions have been conducted with the museum staff. The discussions among other things reveal the museums administration process, procedures, objectives and focuses of each museums as well as some background on the artifacts of the museum. The discussion also talked about the museum agenda, expectations, near future planning, financial information and etcetera. Issues and problems and other issues related to the museum administration and management that may significantly inform the research towards the identification of the project requirement were also discussed.

In addition to the discussion, observations has also been done in each of the museums to gain better understanding and the overall view to get insights on the current state of the artifacts and their information. The discussions and observations took place for a few cycles and any latest information (related to the project) were updated from time to time to the researchers. Besides that, few initial projects have also been executed in order to immerse into the realistic context of the museum. It is a hope that having these initial projects would provide us with firsthand experience as well as help to elevate our understanding of the museum context. As previously mentioned, there are four main museums that need to be taken care of, hence it is not an easy task to clearly identify the different needs and requirements, planning and designing as well as executing the design and development of the museum website and the museum web-based digital exhibit towards successful outcomes. Nevertheless, due to the limitation of time and man power, these initial projects were conducted with focus on selected museums only namely Muzium Padi and Muzium Diraja as both are the most visited museums. The decision was made to follow suit the advice from Lembaga Muzium Negeri Kedah.

\section{Design and Development of the Web-based Exhibit}

Since there are too many artifacts/objects in the museum, we decided to choose one of the exhibits as a prototype. An exhibition from Muzium Diraja, has been chosen to understand both development process of digitizing museum exhibit and user's learning experiences towards using this exhibit. The exhibition focuses on the process of royal wedding which was shown in Museum Diraja in their 'pelamin' section. In this phase, the digital exhibit was developed was placed in a separate website as we need to look at the quality and acceptance before being embedded in the 'Rangkaian Muzium' sub section. It was design using Adobe Flash software and it took about 2 months to complete the design and development. Figure 3.4 display some of the screen shots of the Digital Royal Wedding exhibit of Museum Diraja. 

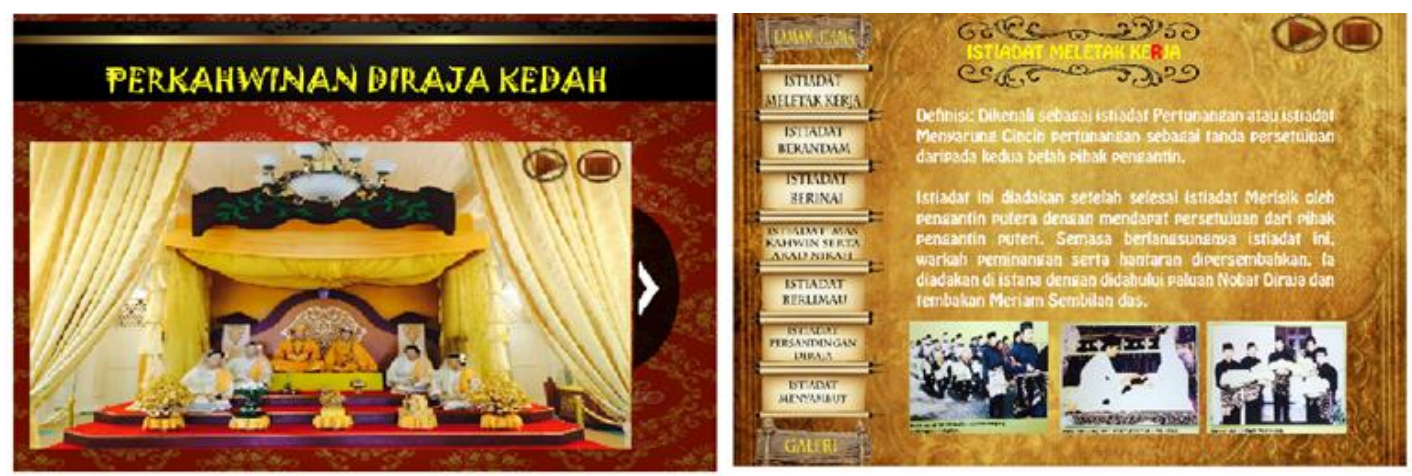

Figure 2: Examples of Digital Exhibits of Royal Wedding for Muzium Diraja

\section{Evaluation of the Web-based Exhibit}

Once the development of the web-based exhibit has been completed, an evaluation session took place. The evaluation was conducted with a group of 12 children aged 9-12 years old. This objective of this evaluation was to understand the usability and users learning experience in using the digital exhibit.

\section{Instruments}

There were two set of instruments developed for this experiment. The first set was the task that needs to be completed by the participants during the procedure. The task given was used to assure that participants were able to use and navigate through the web-based museum's exhibit while finding some information (stated in the instruction of the task to be completed). Then the children were given a set of questionnaire to further clarify their understanding on the usage of the digital museum exhibit. The questionnaire was design to investigate dimension of learning, effectiveness and appeal (Table 1). The questionnaire utilizes four Likert scale suitable for the children ranging from (1) highly agree (SS), (2) agree (S), (3) not agree (TS), and (4) highly not agree (STS). These four types of selection were chosen so that the children can answer the question accurately.

Table 1: The Dimension of the Questionnaire

\begin{tabular}{cl}
\hline Q1 & The application is easy to use \\
Q2 & $\begin{array}{l}\text { Information in this application is easily } \\
\text { understood }\end{array}$ \\
Q3 & $\begin{array}{l}\text { Screen layout is clear } \\
\text { Q4 }\end{array}$ \\
Information that I need is easier to be found \\
\hline \multicolumn{1}{c}{ E - Effectiveness } \\
\hline Q5 & The information helps in completed my task \\
Q6 & I can easily answer the question using this \\
& application \\
Q7 & The interface of this application is clear \\
\hline & \\
\hline Q8 & I like the interface of this application \\
Q9 & The font is readable \\
Q10 & The color is attractive \\
Q11 & The picture is clear \\
Q12 & The picture is easily understood \\
\hline
\end{tabular}




\section{Experimentation Procedure}

The experimentation took place in a computer lab at the School of Multimedia Technology and Communication (SMMTC). This lab was chosen as it provides enough facility to run the experiment in a control environment. Every participant was given a set of tasks to be completed during the experiment and also a questionnaire that need to be answered once they have finished the task. Overall, the participants were given 30 minutes to complete the task on their own (but allowed to ask for clarification on anything they do not understand in completing the task at any time during the experiment). The task given encouraged the participants to browse through the web-based exhibit for fifteen minutes before starting to do the required task. Another fifteen minutes were allocated for them to answer the questionnaire. After the experiment was completed each of the participants were given some token as appreciation for participating in the experiment.

\section{Result}

There were 12 children that took part in the evaluation experiment. Their age ranged from 9 to 12 years old ( $2^{\text {nd }}$ level of primary school). After the evaluation procedure was completed, we analysed the gathered data to get the results. Figure 3 shows the learning aspects of the web-based museum's exhibit. Most of the answers for this dimension was rated as highly agree and agree. It shows that children did learn using the web-based exhibits.

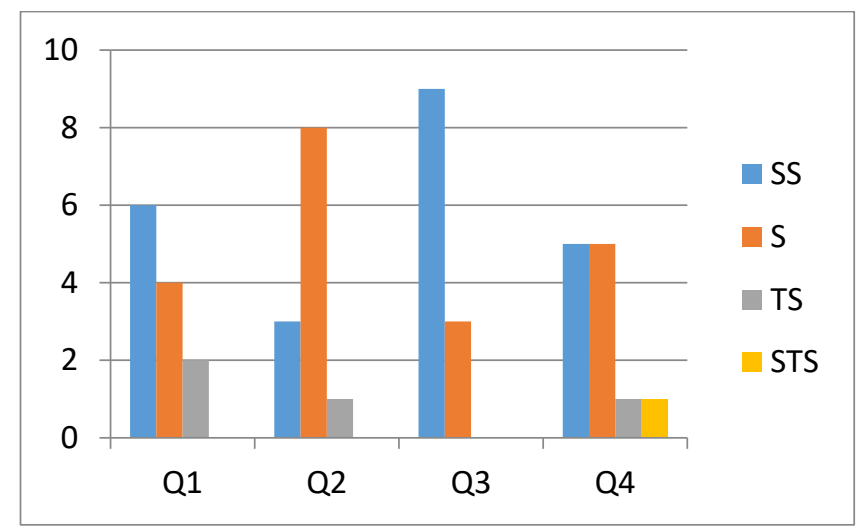

Figure 3: Digital Museum Exhibit Learning Dimension

Figure 4 shows the effectiveness aspects of the web-based museum exhibit. Effectiveness refers to the ability of the application to allow children completing the provided task. Most of the answers for this dimension were also at highly agree and agree which is quite similar to the previous dimension. It shows that the digital exhibit used by the children is effective in helping them to complete their work. 


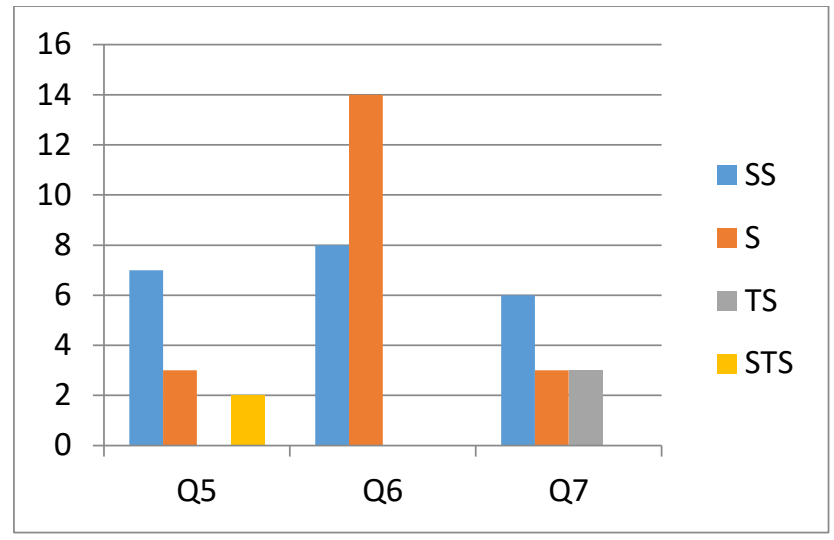

Figure 4: Digital Museum Artifacts Effectiveness Dimension

Figure 5 shows the appeal aspects of the web-based museum exhibit. Answers for this dimension was also very encouraging as mostly rated as highly agree and agree. It shows that the digital exhibit used by the children is appealing.

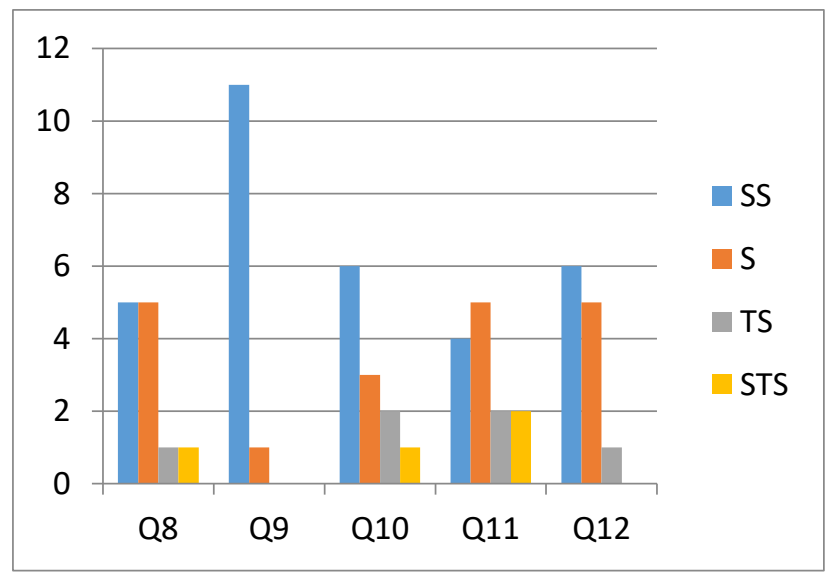

Figure 5: Digital Museum Exhibit Appeal Dimension

\section{Conclusion}

Generally, with reference to the results of this evaluation; we concluded that the small-scale web-based exhibit of the Muzium Diraja has shown positive impact for children museum learning experiences. Factors of learning, effectiveness and appealing play important roles for learning to take place. Therefore it was suggested that this factors need to be taken seriously during design and development of such exhibit. We strongly believed that webbased museum exhibit has a promising future in Kedah Museum.

\section{References}

Ahmad, S., Abass, M. Y., Taib, M.Z.M. \& Masri, M. (2014). Museum Exhibition Design: Communicating of meaning and shaping of knowledge. Social and Behavioral Sciences, 153 (2014), 254-265.

Ahmad, S., Abass, M. Y., Yusof, W.A.Z. M. \& Taib, M.Z.M (2013). Museum Learning: Using research as best practice in creating future museum exhibition. Social and Behavioral Sciences, 105 (2013), 370-382.

Alwi, A. (2013). Understanding Children's Learning from Multimedia Instruction. Proceedings of the International Conference on e-Learning, part of the IADIS Multi 
Conference on Computer Science and Information Systems (MCCSIS), 23-26 July 2013, Prague.

Andre, 1., Durksen, T. \& Volman, M.L. (2017). Museums as avenues of learning for children: a decade of research. Learning Environment Research, 2017(20), 47-76.

Awang, N., Yaakub, A. R. \& Othman, Z. (2009). Assessing User Acceptance towards Virtual Museum: The Case in Kedah State Museum, Malaysia. Paper presented at the Sixth International Conference on Computer Graphics, Imaging and Visualization, Tinjian, 11-14 August 2009.

Birch, J. (2018). Museum spaces and experiences for children - ambiguity and uncertainty in defining the space, the child and the experience. Children's Geographies, 16(5), 516528.

Carr, M., Clarkin-Phillips, J., Beer, A., Thomas, R., \& Waitai, M. (2012). Young children developing meaning-making practices in a museum: the role of boundary objects. Museum Management and Curatorship, 27(1), 53-66.

Falk, J. H., \& Dierking, L. D. (2000). Learning from museums: Visitor experiences and the making of meaning. Walnut Creek, AltaMira Press.

Kechot, A.B.S., Hassan, Z. \& Yunos, Y. (2010). Proses Pendidikan Muzium: Satu Kajian. Jurnal Melayu, (5) 2010, 285-293.

Moorhouse, N., Tom Dieck, M. C., \& Jung, T. (2019). An experiential view to children learning in museums with Augmented Reality. Museum Management and Curatorship, 1-17.

Piscitelli, B., \& Anderson, D. (2001). Young children's Perspectives of Museum Settings and Experiences. Museum Management and Curatorship, 19(3), 269-282.

Sutcliffe, K., \& Kim, S. (2014). Understanding children's engagement with interpretation at a cultural heritage museum. Journal of Heritage Tourism, 9(4), 332-348.

Taha, D. D. A. H. (2008). Museums in Malaysia: Challenges and Development. Kuala Lumpur, Department of Museums, Malaysia. 